\title{
Risk Management Committee, Financial Reporting Quality and Financial Performance of Deposit Money Banks in Nigeria
}

\author{
Joseph Ugochukwu Madugba ${ }^{1}$, Egbide Ben-Caleb ${ }^{1}$, Innocent I. Okpe ${ }^{2}$, Oludare, S. Fadoju ${ }^{3}$, Ben-Caleb Jane \\ Ogochukwu ${ }^{4} \&$ Kingsley Iyke Mbamara ${ }^{5}$ \\ ${ }^{1}$ Department of Accounting and Finance, Landmark University, Omu-Aran, Kwara State, Nigeria \\ ${ }^{2}$ Department of Accounting, Enugu State University of Science and Technology, Enugu Sate, Nigeria \\ ${ }^{3}$ Financial services, Landmark University, Omu-Aran Kwara State, Nigeria \\ ${ }^{4}$ Medical Centre, Landmark University, Omu-Aran Kwara State, Nigeria \\ ${ }^{5}$ Bursary Department, Imo State University, Owerri, Imo State, Nigeria \\ Correspondence: Joseph Ugochukwu Madugba (Ph.D), Department of Accounting and Finance, College of Business \\ and Social Sciences, Landmark University, Omu-Aran, Kwara State, Nigeria.
}

Received: January 22, 2020

Accepted: May 11, 2020

Online Published: September 5, 2020

doi:10.5430/rwe.v11n5p288

URL: https://doi.org/10.5430/rwe.v11n5p288

\begin{abstract}
This Paper examined risk management committee and financial reporting quality on performance of banks in Nigeria with objective of finding out if risk management committee and financial reporting quality affect liquidity of the banks in our study. The data was gotten from annual report of the banks and Central Bank of Nigeria (CBN) statistical bulletin. Out of sixteen deposit money banks, five banks were used for a period of five years 2012-2016. The hypotheses were tested and the result showed that risk management committee does not affect liquidity level of the banks. However, financial reporting quality affect the net assets value per share of banks in Nigeria and the researcher recommended that there is need to strengthen the risk management committee at every banking organization in Nigeria and greater focus should be given to global reporting to ensure that Nigerian banks can compete favourably with that of other developing economies.
\end{abstract}

Keywords: risk management committee, liquidity level, net assets value per share, financial reporting quality

\section{Introduction}

\subsection{Background to the Study}

The recent unprecedented collapse of corporations' world over has directed the attention of corporate managers to effective risk management. In an attempt to provide solution to world implication of financial crisis, International Corporation has identified risk management as the core answer. This is because paramount to every business decision is risk. Risk management is imperative because various issues are put into consideration when risk management is involved. Suffice to say that as world development progressed, the financial systems of various growing economies collapsed. The crux was successive operating or financial risk undertaking by the corporations which necessitated various financial and economic meltdowns. In addition, the untimely intervention of world financial institutions to proffer solutions to nation's money institutions and regulatory bodies prevent this from occurring really traumatized the world. Among the causes of crisis was unnecessary of world most valued currencies. This led firms with high level exposure of those risks to wind-up due to lack of fund to pay up debts.

The 2008 financial crisis was traceable to market participants that soughed for more returns in absence of high interest and inflation rate environment and not duly considering the increase of the risk hence disastrous. Suffice to say that critical market issues were not adequately considered by policy maker and regulatory intuitions. Furthermore, many corporate boards also failed to effectively manage the risk that confronted them not until they were face to face with bankruptcy. According to New York Times of November 16 (2016), infectious greed of the CEOs is where the solution to these problems lies.

Suffice to say that the way and manner in which the financial activities of a firm are communicated to members of the public is also a risk that will affect performance of the firm. This is owing to the fact that the world having been 
reduced to global village through technology, efficient and effective management of risk is displayed in the financial statement as a prove of management efficiency. Inability and inconsistency in doing this scare investors. Kamaruzaaman, Mazlifa and Maisarah (2009) opine that every financial statement is expected to disclose relevant, comparable and understandable information. Reliability connotes that such financial information should be free from error, bias and correctly shows what it is intended to represent (Hassen, 2013). The quality of financial reporting is essential as it influences the financials and shareholders pristinely in making informed economic (investment) decision that enhances the overall market efficiency (IASB, 2005).

To authenticate the crucial nature of this, the government established various bodies charged with the responsibility of issuing guidelines for reporting and management of corporations in Nigeria which include indigenization policy of 1972 which is a codification of British Company legislation of 1922 (Okike, 2002), privatization and commercialization policy Act of 1980, Companies and Allied matters Act of 1990. Currently the Securities and Exchange Commission (SEC) code of 2003 regulates the management of public companies and in 2006 Central Bank of Nigeria issued code of governance for banks. Financial Reporting Council of Nigeria (FRCN) regulates the reporting of listed and none listed firms in Nigeria (Nuraden \& Hasuah, 2015). Recently, the International Financial reporting Standard emerged as widely accepted for financial reporting.

\subsection{Statement of the Problem}

Despite the Numerous legislation and code of governance issued by regulatory authorities, it is very derogatory and disheartening to see that corporate failures have been very incessant all over the world and Nigeria is the hardest hit. The Ajakuta steel complex reduced its workforce from 5000 to 1000 in the year 2007 and few firms in business cannot pay dividend to their equity holders and are still in shamble despite their inability to pay and still they are scheduled on the floors of Nigerian stock exchange market (Madugba and Amah 2016).

The banking sector is the hardest hit as poor risk management and financial reporting have also manifested in none payment of dividend by these banks to their shareholders and limited their expansion which could help broaden their profitability and strengthen their ability to raise capital and secure loans for expansion.

It is against these backdrops that one begins to ask if there are legislations and codes enshrined as guides for the management of Nigerian banks.

Extant literature revealed the studies of Chalaki, Dider \& Riahinezhad (2012), Klai \& Omri (2011) and Yetman \& Yetman (2004), though these studies were abroad they did not consider financial performance and risk management committee. In Nigeria, Akeju \& Babatunde (2017), Onuorah \& Friday (2016) did not consider financial performance. In the above studies, none considered risk management committee as a variable of corporate governance and financial performance. Hence, the urgent need for a study of this nature to examine the effect of risk management committee and financial reporting quality on financial performance of banks in Nigeria.

\section{Literature Review}

\subsection{Corporate Governance}

Corporate governance practices are seen to have great effect to maximization of stakeholder's wealth and to the growth prospects of an economy. Paramount to governance codes is the effective increase in stakeholders' wealth and decrease of risk for investor, magnetism of capital assets and recuperating operations of companies (Alalade, Onadeko \& Okezie, 2014). It is crucial to know that the adoption of code of governance is inevitable especially whilst bearing in mind financial market firmness, asset and cost-effective growth. Permit to say that the essence of a helpful governance scheme is to establish a level of buoyancy that is crucial for the appropriate operations that will enhance economic growth. However, corporate governance has been defined as building credibility, transparency and accountability and of course establishing a valuable flow of disclosure that would engender even business performance (Rogers, 2005). Jenkinson and Mayer (1992) opine that corporate governance is means and structure, organization and dealings of institutions are rapt and controlled, as to enhance extensive shareholders' worth by ornamental interest of other stakeholders. (OECD) (1999) opines that corporate governance has to do with rights and responsibility of individuals in the corporation such as managers, Directors Etc. Corporate performances are concerned with trusting and sustaining the trust within the individuals in the corporation (Rogers, 2006). (Kajola, 2008) opine that it has to do with accurate management of the business and protection of shareholders interest. Corporate governance may be seen as the entire measures and structure which practically identify the rights and responsibilities of players in a corporation. It establishes platform for setting corporate objectives and ensuring its' attainment (Akinsulire, 2006). 
However, one crucial aspect of corporate governance that must be critically considered is risk management. This is because every investor is return conscious and would not want to lose his hard earned naira for anything. According to 2006 code of governance, every quoted bank in Nigeria establishes and maintains a risk management committee charged with responsibility of financial risk management of that corporation.

The risk management committee among others is established by management to ensure that the organization operates effectively and effectively and complies with the regulatory requirement and to ensure that risks are evaluated before embarking on them as to avoid liquidation and bankruptcy of the organization.

\subsubsection{Financial Reporting Quality}

Several definitions of financial reporting quality exist in prior literature among them are the studies of Biddle, Hilary \& Verdi (2009) as cited in Chalaki, et al (2012) opine that it is the accurateness to communicate financial dealings. Financial reporting is a medium through which the accountability of stewardship is rendered to shareholders and stakeholders of organizations. Adebayo (2005) asserted that it is a coordinated manner through which account of operations are rendered by managers to owners of corporations. According to him, every financial report should show clearly resources obtained and existing, the manner it is put to use and results of such operation. However, it is crucial to state that the focus of financial reporting or statement is to communicate to the shareholders and other stakeholders what resources are acquired and how they are applied to generate a result which defines their return and assist them to make informed economic decision.

Honestly, the core objectives of financial reporting quality may be divided into two: To aid investment decision making and for management accountability. This is because investors need financial information in order to know the investment that will yield the highest return with a manageable level of risk. Investment return comprises of dividend and capital appreciation or depreciation. Investors in evaluation of investment opportunities try to decide on the quality and authenticity of a business' future performance hence approximate their expected yields in dividends and assets increase. Financial reports are also used in a wider sense to determine management's ability in harnessing the resources committed to them in running the enterprise. This is because management is not only responsible to owners of a business firm for guardianship and safety of enterprise resources, but much more for their competent and gainful use and for shielding them from adverse economic conditions. Organization performance is very broad and covers issues based on efficiency and effectiveness notion. Honestly, one core solution to ensure good accounting reporting quality is ability of accountants to abide by ethics of the profession.

In this study, financial reporting quality was measured using the accrual method thus:

Accrual model measures the extent of earnings management under existing legislation. The theorist believe that earnings is the most crucial in organizations and when is negatively affected, the company's performance will be affected (Van Tendelo \& Vanstralen, 2005). Thus is calculated as

$\Delta \mathrm{WCit}=$ CFOit $-1+$ CFOit + CFOit $+1+\Delta$ REVit + PPEit $+\varepsilon$

Where: $\triangle \mathrm{WC}=$ is the change in working capital accruals or current accruals from the Statement of cash flows

$\mathrm{CFO}=$ the cash flows from operating activities

$\triangle \mathrm{REV}=$ change in revenue

PPE is property, plant and equipment

\subsubsection{Risk Management Committee}

Emekekwue (2002) asserted that it is future uncertainty about deviation from expected earnings or expected outcome. Suffice to say that it is the potential of gaining or losing something of value. In 2004, COSO developed Enterprise risk management (ERM) critically look at risk management as it concerns organizations. The emphasis was on objective sitting in the entity as it relates to risk assessment as a precondition (Kinyu, Gakuru, Gekara \& Orwa, 2015). Risk assessment is made possible through a coordinated effort of effective internal control system, which assists to identify risk and analyse their possible effect.

In finance and accounting, the focus of risk management entails proper identification and management financial risk which has to do with variations in cash flows and market values initiated by undefined changes in stock prices, interest rates and exchange rates (Democlan, 1997, Smith \& Stulz, 1985, Ogbonna and Ebimobowei (2011)). In this study, risk management committee is represented with the number of members sitting on the board. 


\subsubsection{Liquidity Level}

Liquidity is meeting financial demands as it matures. The liquidity level, then, is a yardstick that determines ability of meeting up with short term debts and obligations. In basic financial analysis, liquidity ratio is crucial because a firm that is consistently having challenges with its short term debt is at verge bankruptcy. It is a reflective measure for continuance of a firm as a going concern. It is advisable for investors to always compare a company's ratios against those of its rivalries, its sectors and its industry and over a period of several years. There are three major types of liquidity ratios the most considered by investors is the current ratio, which will be adopted in this study. It is calculated thus:

$$
\text { Current ratio }=\frac{\text { Current Assets }}{\text { Current Liabilities }}
$$

\subsection{Theoretical Framework}

\subsubsection{Ethical Relativism Theory}

This theory holds that whether an action is right or wrong is a function of acceptable behavioural pattern of the society. According to Velasquez, Andre, Sharks and Meyer (2004) the theorists, there are no widely accepted behavioural standards. This is because different moral beliefs are held by different people since our belief is a function of culture so there are different morals what seen right to one looks wrong to another. This theory encourages one to understand the reason behind beliefs that differ from our own, while at same time it challenges us to investigate our beliefs and values we hold (Adegbie \& Fofah, 2016).

\subsubsection{Arbitrage Pricing Theory}

The theorist argued that return on asset $i$ are subject to a series of actors. It implies that price of a stock is influenced by factors which are: Macro factors and company's specific factors. The theorists crusades that an asset's return can be forecasted by considering relationship which exist between that same asset and many common risk factors. (Ross, 1976, Sharpe 1992, Okodi 2008)

\subsubsection{Resource Dependency Theory}

Olajide and Soyibo (2001) opine that it was urbanized Pfeffer (1973) and further exposited by Pfeffer and Salancik (1978). The theory centres on the core function of directors in making available capital required in an organization for improved performance (Hillman, Canella and Peatzold 2000, Babalola \& Adedipe, 2014 Pfeffer (1973)). The conjecture is a focus on selection of representatives of independent businesses as a way of obtaining resources essential to firm success (Wanyaina \& Olwenye, 2013; Daily et al, 2003; Lang and Lockhart, 1990; Johannisson \& Huse, 2000; Riana, 2008 Abdullah and Valentine, 2009) The theory is vital to firm as presence of many business experts will account for good counsel (Zahra and Pearce, 1989).

This study will adopt the three theories because the theories relate to the study. That is while Ethical Relativist theory focuses on the attitude of people as in what should reported and what should be reported based on morals of the reporter, the Arbitrage Pricing Theory direct our attention to risk management as it affects investment and resource dependency theory is adopted because focussed on mobilizing resources to enhance performance.

\subsection{Empirical Review}

Kinyu, Gakure, Gekara and Orwa (2015) in their study on 62 firms listed on Nairobi securities exchange".. The study used survey research design 62 firms and a sample of 38 firms were studied.. The data were tested using ANOVA, chi-square and correlation analysis with the help of (SPSS) version 21.0. The findings showed that risk management influences performance. The study suggested business quoted in Nairobi Securities Exchange (NSE) should establish risk management committee to improve their day to day operations.

Onuorah and Imene (2016) in a study of 5 companies spread across three major sectors in Nigeria that is manufacturing; service and banking were judgementally selected. The result of the analysis revealed positive association among the variables. It was their opinion that more attention should be placed on code of governance as to inculcate widely accepted reporting standard in the Nigerian emerging market.

Klai and Omri (2011) in an 11 years spanned from 1997- 2007 in Tunisian firms adopted the Nicholas (2002) model (Ball \& Brown, 1968; Collins and Kothari, 1998). Result showed that governance mechanisms affect the quality of financial reporting positively. 
Akeju and Babatunde (2017) in their ten years period study 2006-2015 and secondary data obtained from 40 quoted companies were used to measure financial reporting quality. A significant outcome of the test of hypotheses showed that correct application of corporate governance enhances reporting quality of quoted companies in Nigeria.

Chalaki, Didar and Riahinezhad (2012) in their study which spanned form 2003 - 2011. The McNicholas (2002) model was adopted and multiple regressions and E-views software were employed using 136 firms. The result showed a negative influence among corporate governance attributes, the control variables and financial reporting quality.

Hassan (2013) Data used were secondary and population of the study comprised of 59 listed manufacturing firms classified into four subsector namely foods and beverages (21) twenty one firms, Building materials (12) twelve firms, chemicals and paints (13) thirteen firms and conglomerates (13) thirteen firms. In addition, the study spanned from 2007-2011. Out of 59 firms, 32 firms were considered as sample of the study based on availability of data. The study employed longitudinal balanced panel to measure the difference in sample organizations. The result showed that a significant association exist between monitoring characteristics and financial reporting quality. The Housman specification test showed that the panel result after controlling for random, best suit the population as the fixed effect hypothesis was rejected by the Wald/Ch2 test.

Summary of gap in literature

\begin{tabular}{|c|c|c|c|}
\hline Author & Topic & Methodology & Finding \\
\hline $\begin{array}{l}\text { Kinyu, Gakure, Gekara } \\
\text { and Orwa (2015) }\end{array}$ & $\begin{array}{l}\text { The Impact of Enterprise } \\
\text { Risk Management on } \\
\text { Firm Performance: } \\
\text { Evidence from Sri } \\
\text { Lankan Banking and } \\
\text { Finance Industry }\end{array}$ & $\begin{array}{l}\text { Survey and ex-post-facto: } \\
\text { questionnaire and } \\
\text { secondary data extracted } \\
\text { from annual account of } \\
\text { the banks. }\end{array}$ & $\begin{array}{l}\text { Enterprise risk } \\
\text { management has a } \\
\text { positive impact on } \\
\text { financial performance but } \\
\text { the impact is not } \\
\text { significant. }\end{array}$ \\
\hline $\begin{array}{l}\text { Onuorah and Imene } \\
(2016)\end{array}$ & $\begin{array}{l}\text { Corporate Governance } \\
\text { and Financial Reporting } \\
\text { Quality in Selected } \\
\text { Nigerian Company }\end{array}$ & $\begin{array}{l}\text { descriptive } \\
\text { design }\end{array}$ & $\begin{array}{l}\text { The result of the analysis } \\
\text { revealed positive } \\
\text { association among the } \\
\text { variables }\end{array}$ \\
\hline Klai and Omri (2016) & $\begin{array}{l}\text { Corporate Governance } \\
\text { and Financial Reporting } \\
\text { Quality: } \\
\text { The Case of Tunisian } \\
\text { Firms }\end{array}$ & $\begin{array}{l}\text { Was not mentioned, } \\
\text { however adopted } \\
\text { Nicholas model of (2002) }\end{array}$ & $\begin{array}{l}\text { Result showed that } \\
\text { governance mechanisms } \\
\text { affect the quality of } \\
\text { financial } \\
\text { positively. }\end{array}$ \\
\hline $\begin{array}{l}\text { Akeju and Babatunde } \\
(2017)\end{array}$ & $\begin{array}{l}\text { corporate governance and } \\
\text { financial reporting quality } \\
\text { in Nigeria }\end{array}$ & $\begin{array}{l}\text { Ex-post-facto and } \\
\text { adopted the Nicholas } \\
\text { model of }(2002)\end{array}$ & $\begin{array}{l}\text { A significant outcome of } \\
\text { the test of hypotheses } \\
\text { showed that correct } \\
\text { application of corporate } \\
\text { governance enhances } \\
\text { reporting quality of } \\
\text { quoted companies in } \\
\text { Nigeria. }\end{array}$ \\
\hline $\begin{array}{l}\text { Chalaki, Didar and } \\
\text { Riahinezhad (2012) }\end{array}$ & $\begin{array}{l}\text { Corporate } \text { Governance } \\
\text { Attributes and Financial } \\
\text { Reporting } \\
\text { Empirical Evidence from } \\
\text { Iran }\end{array}$ & Ex-post-facto & $\begin{array}{l}\text { negative influence among } \\
\text { corporate governance } \\
\text { variables and financial } \\
\text { reporting quality. }\end{array}$ \\
\hline
\end{tabular}

From extant literature, most of the empirical studies are outside the shores of Nigeria even then, they did not consider risk management committee as a variable in their study. the study of Onuorah et al (2016) and Akeju et al (2017) are 
in Nigeria only concentrated on corporate governance and financial reporting quality and of course not in the banking sector. But this study considered risk management committee, financial reporting quality and financial performance of banks in Nigeria. More so, we employed the accrual model to measure financial reporting quality, number of members of risk management committee as a measure of risk management committee and net assets value per share and liquidity ratio to measure financial performance which other studies ignored.

\section{Materials and Method}

The study adopted ex-post facto.This design allows the researcher to describe observed events using the data derived from such observation to investigate the association between risk management committee, financial reporting quality and financial performance (Hassan, 2013 and Chalaki, Didar \& Riahinezhad, 2012). The data sourced from the published annual statement of the financial institutions in our study. The dependent variable financial performance is measured by liquidity ratio (LR) and net assets value per share (NAVPS) while the independent variable is risk management committee (RMC) and financial Reporting Quality (ARQ). The ordinary least square regression technique was used for analysis with the aid of SPSS the data was analyzed.

\subsection{Model Specification}

For ease of analysis, the following models were developed to guide the analysis of hypotheses in this study

Model 1

$$
\begin{gathered}
\mathrm{LR}_{\mathrm{it}}=f(\mathrm{RMC},) \\
\mathrm{LR}=\left(\beta 0+\beta_{1} \mathrm{RMC}+\mathrm{et}\right)
\end{gathered}
$$

Model 2

$$
\begin{gathered}
\text { NAVPS }_{\mathrm{it}}=f(\text { FRQ }) \\
\text { NAVPS }==\left(\beta 0+\beta_{1} \mathrm{FRQ}+\text { et }\right)
\end{gathered}
$$

Where $\mathrm{LR}=$ liquidity ratio, NAVPS $=$ net assets value per share, $\mathrm{RMC}=$ risk management committee

FRQ= financial reporting quality

\section{Data Analysis and Discussion}

\begin{tabular}{|c|c|c|c|c|}
\hline & $\begin{array}{l}\text { Coefficients } \\
\text { B }\end{array}$ & $\begin{array}{c}\text { Standardized Coefficients } \\
\text { Beta }\end{array}$ & & \\
\hline Variable & & & $\mathrm{T}$ & Sig. \\
\hline (Constant) & 56.852 & & 4.180 & 0.000 \\
\hline RMC2 & -2.183 & -0.158 & -1.106 & 0.274 \\
\hline $\mathrm{R}$ & 0.158 & & & \\
\hline $\mathrm{R}^{2}$ & 0.025 & & & \\
\hline $\operatorname{Adj} R^{2}$ & 0.005 & & & \\
\hline F-ratio & 1.223 & & & \\
\hline Sig. & 0.274 & & & \\
\hline
\end{tabular}

\section{Hypotheses one}

$\mathbf{H O}_{1}$ : The effect of risk management committee and financial reporting quality on liquidity level of listed banks in Nigeria is not significant.

a. Dependent Variable: LR2
b. Predictor variable: (Risk management committee)
*** indicates the result is significant @ 5\%.

The table above publicized that adjusted coefficient of multiple determinations showed a statistical value of 0.025 . Indicating that about $2.5 \%$ of the total disparity observed in liquidity level is explained by the changes in the predictor variable (Risk management committee) in this study. Implying that only about $97.5 \%$ of the changes is accounted for by other variables other than the variable in this study. The F-ratio of 1.223 further highlights the appropriateness of the model specification and though is not significant at 5\%. We accepted null hypothesis and 
concludes that the effect risk management committee on liquidity level of quoted deposit money banks in Nigeria is not significant

\section{Hypotheses two}

$\mathbf{H O}_{2}$ : The effect of financial reporting quality on net assets value per share of quoted deposit money banks in Nigeria is not significant.

\begin{tabular}{|c|c|c|c|c|}
\hline & $\begin{array}{l}\text { Coefficients } \\
\text { B }\end{array}$ & $\begin{array}{c}\text { Standardized Coefficients } \\
\text { Beta }\end{array}$ & & \\
\hline Variables & & & $\mathrm{T}$ & Sig. \\
\hline (Constant) & 40.917 & & 10.657 & 0.000 \\
\hline FRQ2 & -0.304 & -0.319 & -2.335 & $.024^{* * *}$ \\
\hline $\mathrm{R}$ & 0.319 & & & \\
\hline $\mathrm{R}^{2}$ & 0.102 & & & \\
\hline Adj. $R^{2}$ & 0.083 & & & \\
\hline F-ratio & 5.451 & & & \\
\hline Sig. & 0.024 & & & \\
\hline
\end{tabular}

a. a. Dependent Variable: NAVPS2

b. Predictor variable: (Financial reporting quality)

*** indicates the result is significant @ $5 \%$.

Evidence above supported that the adjusted coefficient of multiple determinations showed a statistical value of 0.102. Indicating that about $10.2 \%$ of the total variation observed in the dependent variable (net assets value per share) is explained by the changes in the predictor variable (financial reporting quality) in this study. Implying that only about $89.8 \%$ of the changes is accounted for by other variables other than the variable in this study. The F-ratio of 5.451 further highlights the appropriateness of the model specification and is also significant at $5 \%$. We rejected the null hypothesis and affirm that financial reporting quality has a positive and significant contact on net assets value per share of deposit money banks in Nigeria.

\subsection{Discussion of Result}

Discussion of the result of hypothesis one

Figure 1 and Table 1 indicate a negative and not significant association involving risk management committee and liquidity level of quoted money deposit banks in Nigeria This is supported by a co-efficient of regression value of -2.183 , indicating that only $21.83 \%$ of the total variations observed in liquidity level of the deposit money banks in our study are explained by the risk management committee. This assertion is curious when compared to the finding of Kinyu, Gakure, Gekara and Orwa (2015) and Klai and Omri (2011) though their studies were not in Nigeria. The finding of Hassan (2013) in Nigeria was not in the banking sector and did not include risk management committee in the study. But this study concentrated on banking sector of Nigerian economy and also included risk management committee which no other previous study in this area have done. The implication of this finding is that risk management committee of deposit money banks in Nigeria has not been effective in the discharge of their responsibilities. This could because of lack of expertise (skill) on the part of members of the committee. This is without prejudice to the qualification of members which was included in this study.

Discussion of result for hypotheses two

Figure 2 and Table 2 showed that financial reporting quality has a coefficient of regression value of -0.304 . This indicates significant but negative association involving financial reporting quality net asset value per share. This corroborates the study of Akeju and Babatunde (2017), implying that quality financial reporting will improve the financial performance. 


\section{Conclusion and Recommendations}

We tested risk management committee and financial reporting quality on financial with the major objective of finding out if risk management committee and financial reporting quality affects financial performance. The outcome of revealed:

-Risk management committee negatively and insignificantly affect the liquidity level of the deposit money banks in our study. This finding is curious when compared with the findings of Hassan (2013), though the study was in Nigeria, it was not in the banking sector but manufacturing and it never considered risk management committee as a variable in the study.

-That financial reporting quality negatively but significantly affects the net assets value per share of deposit money banks in our study.

\subsection{Recommendations}

-Risk management in various banking organizations should be strengthened as least to ensure that risks are always evaluated.

- Qualification should be a prerequisite for enlistment of members into the risk management committee at every bank.

-Good team experts should be meant to be members of risk management committee.

-Financial information should be reported with integrity and honesty to avoid misguiding the investing publics.

-There should be greater focus on global standard for financial reporting in Nigerian deposit money banks to enable the Nigerian economy measure up with those of other developing economies.

\subsection{Contribution of the Study}

This study has established that risk management committee and financial reporting quality improves financial performance of banks in Nigeria. Furthermore, it is also the first study to consider risk management committee in a study of this nature and is the most current study.

\section{References}

Abdullah, H., \& Valentine, B. (2009). Fundamental and ethics theories of Corporate Governance. Middle Eastern Finance and Economies, 4, 88-96.

Adebayo, A. (2005). Financial reporting: An aid to efficient economic management in the public sector. The Nigerian Accountant, 38(1), 33-38.

Adegbie, F. J., \& Fofah, E. T. (2016). Ethics, Corporate governance and financial reporting in the Nigerian Banking Industry. Global role of International Reporting Standards, 5(1), 1-14.

Akeju, J. B., \& Babatunde, A. A. (2017). Corporate governance and financial reporting quality in Nigeria. International Journal of Information Research and Review, 4(2), 3749-3753.

Akinsulire, O. (2006). Financial Management (4th ed.). Lagos: El-Toda Ventures.

Alalade, Y. S. A., Onadeko, B. B., \& Okezie, F. O. (2014). Corporate governance practices and firms' financial performance of selected manufacturing companies in Lagos State, Nigeria. International Journal of Economics, Finance and Management Sciences, 2(5), 285-279. Retrieved from www.sciencepublishinggroup.com/j/ijefm

Babalola, A., \& Adedipe, O. A. (2004). Corporate Governance and sustainable Banking sector: Evidence from Nigeria. Research Journal of Finance and Accounting, 5(12).

Ball, R., \& Brown, P. (1968). An Empirical Evaluation of Accounting Income Numbers. Journal of Accounting Research, 6(2), 159-178.

Biddle, G. C., Hilary, G., \& Verdi, R. S. (2009). How does Financial Reporting Quality Relates to investment efficiency?. Journal of Accounting and Economics, 48, 112-131.

Chalaki, P., Didar, H., \& Raihinezhad, M. (2012). Corporate Governance Attributes and Financial Reporting Quality: Empirical Evidence from Iran. International Journal of Business and Social science, 3(15).

Collins, D., \& Kothari, S. (1989). An Analysis of Inter-termporal and Cross-sectional Determinants of Earnings Response Coefficients. Journal of Accounting and Economics, 11, 143-181. 
Daily, C. M., Dalton, D. R., \& Canella, A. A. (2003). Corporate Governance: Decades of Dialogue and Data. Academy of Management Review, 28(3), 371-382.

Emekekwue, P. (2002). Corporate financial management African Bureau of Educational Sciences (4th ed.). Kinshasa- Democratic Republic of Congo.

Hassen, S. U. (2013). Financial Reporting Quality, Does Monitoring Characteristics Matter? An Empirical Anaysis of Nigeria Manufacturing Sector. The Business and Management Review, 3(2).

Hillman, A., Cannella, A., \& Paetzold, R. (2000). The Resource Dependence Role of Corporate Directors: Strategic Adaptation of Board Composition in Response to Environmental Change. Journal of Management Studies, 37(2), 235-256.

IASB. (2005). Exposure draft on an improved conceptual Framework for financial reporting and qualitative characteristics of decision-useful financial reporting information. London.

Jenkinson, T., \& Mayer, C. (1992). The assessment: corporate governance and corporate control. Oxford Review of Economic Policy, 8(3), 138-156. https://doi.org/10.1093/oxrep/8.31

Kajola, S. O. (2008). Corporate Governance and firm performance: the case of Nigeria Listed firms. European Journal of Economics, Finance and Administrative Sciences, (14). Retrieved from http://www.eurojournal.com

Kamaruzaman, A. J., Mazlifa, M. D., \& Maisarah, A. R. (2009). The Association between firm Characteristics and Financial Statement Transparency: the case of Egypt. International Journal of Accounting, 18(2), 211-223.

Kinyu, J., Gakure, R., Gekara, M., \& Orwa, G. (2015). Effect of risk management on the financial performance of companies quoted in the Nairobi Securities Exchange. International Journal of Business \& Law Research, 3(4), 26-42.

Klai, N., \& Omri, A. (2011). Corporate governance and Financial Reporting Quality: The Case of Tunisian Firms. International Business Research, 4(1).

McNicholas, F. (2002). Discussion on the Quality of Accrual Earnings: The Role of Accrual Estimation Errors. The Accounting Review, 77, 61-69.

OECD. (1999). OECD principles of corporate governance Adhoc task force on corporate governance OECD. Paris.

Ogbonna, G. N., \& Ebimobowei, A. (2011). Ethics compliance by the Accountant on the Quality of financial Reporting and Performance of Quoted Companies in Nigeria. Asian Journal Business Management, 3(3), $152-160$.

Onuorah, A. C., \&Imene, O. F. (2016). Corporate governance and Financial Reporting Quality in Selected Nigerian Company. International Journal of Management Sciences and Business Administration, 2(3).

Pfeffer, J. (1972). Size and compensation of corporate board of directors. Administrative Sciences Quarterly, 17, 221-228.

Rogers, M. (2005). Corporate governance and financial performance of selected commercial banks in Uganda. Journal of Accounting Research, 231-262.

Rogers, M. (2006). Corporate governance and financial performance of selected commercial banks in Uganda. Kampala Uganda. East Africa: Marketers University Business School, Faculty of Commerce.

Van Tendelo, B., \& Vanstraelen, A. (2005). Earning Management under German GAAP versus IFRS. European Accounting Review, 14(1), 155-180.

Velasquez, C. A., Andre, T., Sharks, S. J., \& Meyer, M. J. (2004). Ethics Relativism Theory. Santa Clara University, Silicon Valley.

\section{Copyrights}

Copyright for this article is retained by the author(s), with first publication rights granted to the journal.

This is an open-access article distributed under the terms and conditions of the Creative Commons Attribution license (http://creativecommons.org/licenses/by/4.0/). 